Guest Editorial, part of a Special Feature on Sustainably Managing Freshwater Resources

\title{
Sustainably managing freshwater resources
}

\author{
$\underline{\text { Suzie Greenhalgh }}^{1}$ and $\underline{\text { Oshadhi Samarasinghe }}^{1}$
}

Key Words: collaboration; governance; indigenous people; management; participation; policy

\section{INTRODUCTION}

Sustainable management of freshwater resources is becoming more complex and challenging in many areas around the globe. This is driven by a multitude of pressures that make the governance and management of fresh water less than straightforward. Some of these pressures include water scarcity and declining water quality alongside urban expansion, population growth, agricultural intensification, environmental justice, indigenous rights, and biodiversity loss.

A common response by governments to more sustainable freshwater management is to move from consultative to more participatory approaches, in other words moving away from gathering information/feedback from the public (consultation) to where the public is involved in the decision making (collaboration; IAP2 2014). This move toward collaboration is to achieve consensus outcomes that deliver the most benefits to the largest number of stakeholders while achieving desirable environmental outcomes (Cradock-Henry et al. 2017). Often participatory approaches are driven by or are encompassed in legislation. In New Zealand, for instance, national dialogues (Land and Water Forum 2012), the National Policy Statement for Freshwater Management (NPSFM; MfE 2014), and now the Resource Legislation Amendment Act (MfE 2018) which governs natural resource management include an option for collaborative planning. Likewise in Tanzania the formation of Water User Associations (WUAs) was a legal requirement under the Water Resources Management Act (2009) and formalized community participation (van Koppen et al. 2007, Kabogo et al. 2017). It is within this legal, political, social, environmental, and economic backdrop that this special feature sits.

The objective of this special feature is to document, explore, and demonstrate new, emerging, and enhanced governance, policy, and decision-making paradigms for sustainably managing freshwater resources. Much of the evidence comes from New Zealand, which is undergoing dramatic national and regional reforms in the management of its freshwater resources. These reforms provide a dynamic environment from which to draw conclusions about the effectiveness of decision making and the knowledge and processes that underpin them. Alongside these learnings we provide evidence and experience from other parts of the world. The insights drawn from the experiences in New Zealand and other jurisdictions are highly relevant to many parts of world. In particular, those places where agriculture uses large quantities of water, is a primary nonpoint source of water quality contaminants (nitrogen, phosphorous, sediment, and bacteria), or where there are competing freshwater demands.

In the papers in this feature we pay particular attention to the role of people in the governance and management of freshwater resources. We are particularly interested in the integration of the human and environmental dimensions at the land-water interface. We also include insights into the changing role of indigenous people in the management of freshwater resources.

\section{KEY RESEARCH INSIGHTS IN THIS EDITION}

The topics covered by this special feature include (1) collaborative and participatory approaches to management, (2) values to support decision making, (3) the effectiveness of institutional frameworks, (4) emerging roles of indigenous peoples in freshwater management, and (5) frameworks and lessons for policy choice and design.

When contemplating the governance approach for making freshwater decisions, the type of governance arrangement is important. Hughey et al. (2017) compare a number of freshwater management cases from Australia and New Zealand using a framework that looks at scope, governance, and management. This framework provides a means to compare the multilevel and polycentric nature of collaborative arrangements evident in Australian and New Zealand freshwater management. In both Australia and New Zealand, freshwater management is the responsibility of local government (Department of the Environment and Energy 2011, MfE 2014), although there are national directions provided, e.g., National Water Initiative (2004) framework and National Water Quality Management Strategy in Australia and the NPSFM in New Zealand. Participatory approaches are also an important aspect of natural resource governance and management in both countries (Benson et al. 2012, MfE 2014). Based on their comparison of different arrangements Hughey et al. posit the core ingredients of an ideal governance approach include flexible but long-term arrangements, focus on a specific array of values deemed important to partners, and equitable resourcing. The participants in these governance approaches need to be aware of the interplay between partnering and managing.

Values, what they are and who holds them, are an integral part of more collaborative and participatory approaches to freshwater management. The paper by Tadaki et al. (2017) seeks to clarify environmental values and valuations for use in freshwater management, an area of much confusion and contention in their interpretation and use. The authors outline four different concepts of value and encourage practitioners to think about value methodologies as "technologies of participation." They suggest the choice of value concept and method needs to be situated within the relevant place and history, and that values can be used to facilitate citizen empowerment and environmental democracy.

Building on the concept of value, Harmsworth et al. (2016) place Māori (the indigenous people of New Zealand) values within an 
indigenous people's world view. They outline some of the cultural monitoring methods that have evolved to support the articulation of Māori values and their use in decision-making processes. The development of these indigenous-based frameworks and tools are being driven by (1) emerging models of cogovernance, coplanning, and comanagement between government and iwil hapū (tribe) for freshwater resources in New Zealand (largely derived through Treaty of Waitangi settlement process), and (2) increased use of collaborative approaches. As a result the rights and role of Māori and the consideration of the values Māori hold for water play a prominent part in legislative reform, and continuing policy and plan development.

The frameworks and tools outlined by Harmsworth et al. can be seen as exemplars for the integration of indigenous knowledge and concepts into national policy frameworks and regional/local governance and management regimes. Harmsworth et al. noted two key elements to the success of collaborative processes for Māori: (1) enduring relationships between local government and Māori, and (2) adequate resourcing for all partners contributing to collaborative decision-making processes.

Hemming et al. (2017) document a different approach being taken in Australia with regard to the participation of indigenous peoples in the management of freshwater resources. The nation-building approach described in this paper differs from the approaches evolving in New Zealand. This partly reflects the absence of a treaty to underpin rights while also drawing on similar principles as those in New Zealand, e.g., building the capacity to partner, long-term partnership, and recognition of the vision and values of indigenous people for the land and water. Both Harmsworth et al. and Hemming et al. provide key learnings and approaches for how to engage, support, enable, and partner with indigenous people in the management of freshwater resources. Both show that to effectively recognize the role of indigenous peoples requires the acknowledgement and embedding of customary relationships alongside the legislative framework(s) that govern the freshwater management decisions.

While Harmsworth et al. and Hemming et al. take an indigenous perspective of empowering citizen engagement and participation in managing freshwater resources, Storey et al. (2016) explores how community monitoring efforts can enhance citizen involvement. By demonstrating the agreement between community (citizen) and local government (professional) monitoring Storey et al. show community monitoring could augment professionally collected data. They also show that involvement in monitoring increased wider community awareness of the condition of local fresh waters and decision-making processes for freshwater management.

As noted earlier, more collaborative approaches to formal local government planning processes are being used in New Zealand. Although these more participatory and collaborative governance models are promising and can deliver more enduring outcomes, there is much to be learned by critically examining existing examples and models to improve their implementation. CradockHenry et al. (2017) and Sinner et al. (2016) examine some collaborative processes to provide insights into New Zealand's journey. In terms of the participants within collaborative processes, Cradock-Henry et al. noted that dynamic internal and external conditions mean that processes and their participants need to be able to incorporate feedback and adapt to these changing conditions. So, although these processes tend to build social capital and trust (and therefore more enduring relationships), the nature of the participants, their support for the process, and the design of the process all influence (positively and negatively) the progress of collaborative processes.

One metric for the success or failure of collaboration is the public's acceptance of the process and the outcomes being determined by a collaborative process. Sinner et al. test this for three regions in New Zealand to find that community knowledge of collaborative processes was generally low, and living in a catchment ${ }^{[1]}$ with a collaborative process did not always affect perceptions of management, agreement, fairness, or interest in the process. People in one catchment with a collaborative process, however, did believe that water management was better and fairer and they perceived less conflict compared to those living outside the catchment with a collaborative process. One interesting result was that people who actively participate in planning processes have less favorable perceptions of the ability of local government to manage fresh water. Although a number of things may drive this finding, such as those with less favorable perceptions are more likely to participate or collaboration is undertaken in highly conflicted catchments, it does show the importance of tracking perceptions over time to inform public outreach and process design.

Tanzania has a different model for public participation in freshwater management: the creation of formally recognized water users' associations (WUAs) within a nested water governance system. More than a decade after implementation, Kabogo et al. (2017) document Tanzania's journey and examine the strengths and challenges of these WUAs. Capacity (leadership and skills), awareness (legal frameworks and role of WUAs), and resourcing (mostly funding and environmental data) limitations hinder participation, operational management of the WUAs, and willingness to and ability of the associations to enforce management decisions, e.g., payment of water fees. On the flip side, the WUAs provide a formal mechanism for stakeholder participation and therefore a voice for these local stakeholders in water basin-scale decisions as well as helping with conflict resolution. In addition, in some areas these WUAs have provided a community building role through the sharing of knowledge that is wider than just water issues, e.g., agricultural extension. These challenges and strengths reflect many of those identified by other authors, but Kabogo et al. suggest that the creation of spaces for shared learning and collaboration between WUAs could effectively address some of the capacity and awareness challenges.

Another key component of freshwater management is the policies that will govern future freshwater management. Whether the design of policy and/or choice of policy instruments are determined using participatory or more command and control (top-down) approaches, these choices are not easy. Kaine et al. (2017a) posit that these choices can be made more challenging when equity and efficiency objectives are confounded in a policy. They use equity and efficiency as two separate objectives to help clarify and facilitate the policy deliberations for freshwater management. These insights were to help policy makers during policy formulation and design to avoid policy failure by reducing 
the potential influence from self-interested parties and their concerns about welfare.

When choosing between policy instruments, Kaine et al. (2017b) noted that the choice of instruments needed to align with the fundamental cause of the behavior the policy intends to change. They describe a framework, the Policy Choice Framework, to help select a policy instrument to change behaviors that create the natural resource problems. The framework also considers how people, both affected parties and policy administrators, interact with the proposed policy instruments. Moreover, they identified three critical influences to policy instrument choice: whether economies of scale are present, whether the change in peoples' behavior should be voluntary or compulsory, and whether it is practical to measure outcomes or actions of people.

The paper by Huntsinger et al. (2017) looks at freshwater management and policy signals and the inherent complexity in these decisions to say that future management signals should not only acknowledge different values but should also acknowledge history, in other words acknowledge how the ecological system has already responded to past management decisions. To demonstrate the importance of historical decisions they use an example in California where habitat (ponds and wetlands) for the now threatened species, California Black Rail (Laterallus jamaicensis coturniculus), was inadvertently created at the nexus of local governance, plentiful water, agricultural practices, historical events, and changing land uses. If history is ignored and the new social-ecological system that created this landscape is unravelled it will lead to the loss of valuable habitat. Therefore, future freshwater management, regardless of the decision-making process, should recognize the legacy of past decisions.

This is particularly important in California where the Sustainable Groundwater Management Act 2014 (SGMA) is signaling new ways to manage the state's groundwater resources. SGMA created a framework for sustainable, local groundwater management that recognizes the connection between surface water and groundwater and linkage with land use (California Environmental Protection Agency et al. 2014, State of California 2014). It covers both water use and water quality. Simultaneously, the California Department of Water Resources has implemented regulations to address nitrate contamination in drinking water (Harter et al. 2012, Rosenstock et al. 2014). In this new legislative context it will be important to ensure that the drive to increase water use efficiency to address water scarcity does not further threaten species habitat.

Our last paper addresses the ethical issues associated with collective knowledge creation and sharing between researchers and practitioners. Ayre et al. (2018) reminds us as researchers of the importance of understanding and reflecting on how we approach action research into freshwater management and governance. Moreover, they highlight the value of, and types of dilemmas inherent in, using collaborative models to work across the research-practice interface. By recognizing there are four interlinked and iterative phases for freshwater management research-practice, coinitiation, codesign, coimplementation, and coevaluation, we can better support more effective and ethical collective research and practice. Recognizing these phases will lead to more effective and ethical research-practice by (1) sensitizing collaborators to the need for reflexivity from the initiation of cocreation processes, (2) proposing action research codesign as a method for managing emergent questions and outcomes, and (3) supporting more equitable outcomes for collaborators through an emphasis on coevaluation and collaborative articulation of the links between research outputs and practice outcomes.

\section{IN SUMMARY}

The papers in this special feature have explored, documented, and demonstrated some of the changing decision-making paradigms for fresh water, providing a number of insights for researchers, practitioners, and decision makers. Some of the key insights include the following:

- Values, what they are and who holds them, are an integral part of more collaborative and participatory approaches to freshwater management.

- To effectively recognize the role of indigenous people in freshwater management requires building long-term relationships and embedding customary relationships within policy.

- Capacity and resourcing is a constraint that often inhibits the ability of communities, indigenous and nonindigenous, to engage or manage freshwater resources effectively.

- Community and cultural monitoring can play important roles in augmenting professional monitoring and articulating lesser documented indigenous values.

- Partnership is an important aspect for effective freshwater governance and management regimes as well as research practice.

- To increase the potential for success of collaborative processes, attention should be paid to the dynamic internal and external conditions to help adjust processes and outreach strategies, and to the nature of participants in the process.

- The decisions of the past can create new social-ecological systems that should be acknowledged, considered, and accounted for in future freshwater regimes.

- Avoiding the conflation of policy objectives and aligning policy choices with the behaviors that need to change can help decision-making processes and potentially reduce conflict.

- Paying attention to the interlinked and iterative phases of cocreation and the ethical dilemmas that arise within each phase will lead to more effective and ethical researchpractice.

[1] "Catchment" is another term for watershed in some parts of the world such as New Zealand and Australia.

Responses to this article can be read online at: http://www.ecologyandsociety.org/issues/responses. php/10233 


\section{Acknowledgments:}

We would like to thank New Zealand's Ministry of Business Innovation and Employment's Science and Innovation Group, who funded the Freshwater Values, Monitoring and Outcomes (VMO) research Programme (C09X1003), from which 8 of the 12 papers came. We thank the many stakeholders in New Zealand who participated in, supported, and engaged with the many aspects of these papers. Without them the learnings would not have been as meaningful or relevant to the ongoing reforms to freshwater governance and management within New Zealand. We also thank the other authors and their stakeholders who provided additional experiences and insights to share and enhance the governance of and decision-making processes for our precious freshwater resources. We would also like to give a special mention to Dr Philip Wallis, one of the authors in our special edition, who sadly passed away during its publication. Dr Wallis made many contributions in Australia bringing together researchers, policy makers, NGOs, and industry to reframe and enact collaborative water governance and planning for climate change adaptation and catchment management, and will be sadly missed.

\section{LITERATURE CITED}

Ayre, M. L., P. J. Wallis, and K. A. Daniell. 2018. Learning from collaborative research on sustainably managing fresh water: implications for ethical research-practice engagement. Ecology and Society 23(1):6. http://dx.doi.org/10.5751/ES-09822-230106

Benson, D., A. Jordan, and D. Huitema. 2012. Involving the public in catchment management: an analysis of the scope for learning lessons from abroad. Environmental Policy and Governance 22(1): 42-54. http://dx.doi.org/10.1002/eet.593

California Environmental Protection Agency, California Natural Resources Agency, California Department of Food \& Agriculture, California Department of Water Resources, California Water Boards, Association of California Water Agencies, Groundwater Resources Association of California, and University of California. 2014. Groundwater legislation implementation fact sheet. California Environmental Protection agency, California Natural Resources Agency, California Department of Food \& Agriculture, California Department of Water Resources, California Water Boards, Association of California Water Agencies, Groundwater Resources Association of California, and University of California, Oakland, California, USA. [online] URL: http://groundwater.ucdavis.edu/files/203049. pdf

Cradock-Henry, N. A., S. Greenhalgh, P. Brown, and J. Sinner. 2017. Factors influencing successful collaboration for freshwater management in Aotearoa, New Zealand. Ecology and Society 22 (2):14. http://dx.doi.org/10.5751/ES-09126-220214

Department of the Environment and Energy. 2011. Water management in Australia. Department of the Environment and Energy, Canberra, Australia. [online] URL: https://soe. environment.gov.au/science/soe/2011-report/4-inland-water/4effectiveness/4-1-water-management

Harmsworth, G., S. Awatere, and M. Robb. 2016. Indigenous Māori values and perspectives to inform freshwater management in Aotearoa-New Zealand. Ecology and Society 21(4):9 http://dx. doi.org/10.5751/ES-08804-210409

Harter, T., J. R. Lund, J. Darby, G. E. Fogg, R. Howitt, K. K. Jessoe, G. S. Pettygrove, J. F. Quinn, J. H. Viers, D. B. Boyle, H. E. Canada, N. De La Mora, K. N. Dzurella, A. Fryjoff-Hung, A. D. Hollander, K. L. Honeycutt, M. W. Jenkins, V. B. Jensen, A. M. King, G. Kourakos, D. Liptzin, E. M. Lopez, M. M. Mayzelle, A. McNally, J. Medellin-Azuara, T. S. Rosenstock. 2012. Addressing nitrate in California's drinking water with a focus on Tulare Lake Basin and Salinas Valley groundwater. Report for the State Water Resources Control Board Report to the Legislature. Technical Report, Center for Watershed Sciences, University of California, Davis, California, USA.

Hemming, S., D. Rigney, S. L. Muller, G. Rigney, and I. Campbell. 2017. A new direction for water management? Indigenous nation building as a strategy for river health. Ecology and Society 22 (2):13. http://dx.doi.org/10.5751/ES-08982-220213

Hughey, K. F. D., C. Jacobson, and E. F. Smith. 2017. A framework for comparing collaborative management of Australian and New Zealand water resources. Ecology and Society 22(4):28. http://dx.doi.org/10.5751/ES-09582-220428

Huntsinger, L., T. V. Hruska, J. L. Oviedo, M. W. K. Shapero, G. A. Nader, R. S. Ingram, and S. R. Beissinger. 2017. Save water or save wildlife? Water use and conservation in the central Sierran foothill oak woodlands of California, US. Ecology and Society 22(2):12 http://dx.doi.org/10.5751/ES-09217-220212

International Association for Public Participation (IAP2). 2014. IAP2's public participation spectrum. IAP2, Louisville, Colorado, USA. [online] URL: https://www.iap2.org.au/Tenant/C0000004/00000001/ files/IAP2 Public Participation Spectrum.pdf

Kabogo, J. E., E. P. Anderson, P. Hyera, and G. Kajanja. 2017. Facilitating public participation in water resources management: reflections from Tanzania. Ecology and Society 22(4):26. http:// dx.doi.org/10.5751/ES-09739-220426

Kaine, G., S. Greenhalgh, W. Boyce, R. Lourey, J. Young, E. Reed, B. Keenan, and S. Mackay. 2017a. A microeconomic perspective on the role of efficiency and equity criteria in designing natural resource policy. Ecology and Society 22(1):50 http://dx.doi. org/10.5751/ES-09133-220150

Kaine, G., J. Young, R. Lourey, and S. Greenhalgh. 2017b. Policy choice framework: guiding policy makers in changing farmer behavior. Ecology and Society 22(2):2. http://dx.doi.org/10.5751/ ES-09135-220202

Land and Water Forum. 2012. Second report of the Land and Water Forum: setting limits for water quality and quantity, and freshwater policy-and plan-making through collaboration. Land and Water Forum, Wellington, New Zealand. [online] URL: http://www.landandwater.org.nz/Site/Resources.aspx\#H126743-8

Ministry for the Environment (MfE). 2014. National policy statement for freshwater management 2014. Ministry for the Environment, Wellington, New Zealand.

Ministry for the Environment (MfE). 2018. About the Resource Legislation Amendment Act 2017. Ministry for the Environment, Wellington, New Zealand. [online] URL: http://www.mfe.govt. 


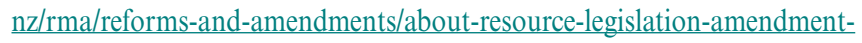
act-2017

Rosenstock, T. S., D. Liptzin, K. Dzurella, A. Fryjoff-Hung, A. Hollander, V. Jensen, A. King, G. Kourakos, A. McNally, G. S. Pettygrove, J. Quinn, J. H. Viers, T. P. Tomich, and T. Harter. 2014. Agriculture's contribution to nitrate contamination of Californian groundwater (1945-2005). Journal of Environmental Quality 43:895-907. http://dx.doi.org/10.2134/jeq2013.10.0411

Sinner, J., P. Brown, and M. Newton. 2016. Community perceptions of collaborative processes for managing freshwater resources. Ecology and Society 21(4):5 http://dx.doi.org/10.5751/ ES-08851-210405

State of California. 2014. Sustainable groundwater management act. State of California, Sacramento, California, USA. [online] URL: http://opr.ca.gov/docs/2014 Sustainable Groundwater Management Legislation 092914.pdf

Storey, R. G., A. Wright-Stow, E. Kin, R. J. Davies-Colley, and R. Stott. 2016. Volunteer stream monitoring: Do the data quality and monitoring experience support increased community involvement in freshwater decision making? Ecology and Society 21(4):32 http://dx.doi.org/10.5751/ES-08934-210432

Tadaki, M., J. Sinner, and K. M. A. Chan. 2017. Making sense of environmental values: a typology of concepts. Ecology and Society 22(1):7. http://dx.doi.org/10.5751/ES-08999-220107

Van Koppen, B., C. S. Sokile, B. A. Lankford, N. Hatibu, H. Mahoo, and P. Z. Yanda. 2007. Water rights and water fees in rural Tanzania. Pages 143-163 in F. Molle and J. Berkoff, editors. Irrigation water pricing: the gap between theory and practice. $\mathrm{CAB}$ International, Wallingford, UK. http://dx.doi.org/10.1079/9781$\underline{845932923.0143}$ 